\title{
PROFILE：GEORGES APERGHIS
}

Georges Aperghis was born in Athens in 1945 and has lived and worked in Paris since 1963. In 1976 he founded ATEM (Atelier Théâtre et Musique), reinventing his approach to composition via a new art form that transposes issues of everyday life and society into an often absurd and poetic world, in which musicians, singers, actors and multimedia artists meet on an equal footing. After leaving ATEM in 1997, Aperghis continued to write musical plays (Machinations, 2000; Paysage sous surveillance,

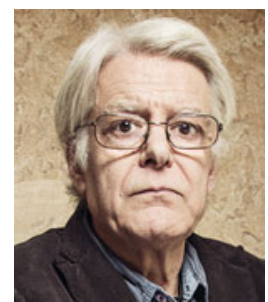

Georges Aperghis photographed by Xavier Lambours 2002; Le petit chaperon rouge, 2003; Luna Park, 2011). His concert music, too, reveals his taste for experimentation and a certain kind of provocation, but nothing is intentionally stageoriented, all is composition-driven. His operas may be considered a synthesis of his musical theatre and concert music: here, the text is the unifying and decisive element, and the singing voice is the main vector of expression. Aperghis has composed seven lyrical works, including Pandemonium (1973), Liebestod (1981), Tristes tropiques (1996) and Les Boulingrin (2010). A prolific composer with a neverending inventiveness, Georges Aperghis is building a very personal corpus of works, serious and humorous at the same time, rooted in tradition as well as free of institutional constraints.

Q. What is inspiring you at the moment?

A. Generally speaking, it's the musicians for whom I write that inspire me. For example, at the moment I am writing for Calefax ensemble (Amsterdam), so I am thinking a lot about them. I had the time to meet each member, with their instrument, and it was very inspiring for me. Otherwise, inspiration is day-to-day work, not something that falls from the sky.

Q. Which work of art (of any medium) has most affected you recently?

A. I was in Rome recently, where I revisited the Caravaggios in the church of San Luigi dei Francesi and was, once again, enormously moved. It's like painting in $3 \mathrm{D}$, with the most incredible capturing of light.

Q. What's afoot in the new music scene in Paris?

A. I never go out in the evening so I'm not really in a position to talk about the Parisian scene!

Q. What current developments or trends do you perceive in the world of contemporary music?

A. I mix with young composers a fair bit, especially at Darmstadt, and I think that, beyond the easily recognisable influences, there are plenty of characters that really take their own direction; one can't really talk about general tendencies. 
Q. What are you reading at the moment?

A. I have just finished an utterly captivating book by a young French author, Victor Lebrun, who was Tolstoy's secretary. He gives us almost the daily details of the great writer's life and work.

Q. How would you describe your music?

A. I can't describe my music except by writing my music.

Q. How has your compositional process evolved over the years?

A. I compose every day; things change little by little through the regularity of this daily work. Then there is the impact of encounters with musicians, writers and painters, and also with electronic music that really opened up new horizons for me. I never look backwards, so I wouldn't know how to describe my evolution.

Q. What are you hoping your legacy will be?

A. A certain idea of freedom.

Q. Which pieces of music could you not live without?

A. The list would be long ... I suppose it changes all the time but, in general, Bach and Beethoven would be on there.

Q. What does collaboration mean to you?

A. A permanent and continuous back-and-forth between my collaborators and me. Often I put a lot of trust in the artists with whom I work, and my ideas emerge as I speak with them.

Q. After your long collaboration during the '70 s and ' $80 \mathrm{~s}$ with Antoine Vitez and your work with ATEM, what conclusions do you draw about music theatre?

A. I can't come to any conclusions about music theatre in general; I try, in my way, to keep alive the spirit of ATEM in all that I do, even if the results are very different. Each project has its own singularity so it's impossible for me to draw conclusions about the 'genre'. For me, it's the only way to keep moving forwards: to resist thinking in terms of an overview.

Q. Multimedia has been something of an important preoccupation for you recently. What attracts you to this territory?

A. It's more that it is a world that is all around us today, that reflects itself back upon our musical scene. But it depends upon the project: there are pieces that simply don't call for video or electronics. Technology must have function, otherwise I just don't use it.

Q. You celebrate your seventieth birthday this year: what does 2015 hold?

A. At the moment that I'm writing this, 2015 is already well under way: I have just returned from trips to Munich (where my new pieces for orchestra were premiered by Bayerischer Rundfunk), Salzburg (for a performance of Luna Park in the Biennale), Berlin (for three concerts in Maerzmusik, one of which was a performance of Situations - une convivialité musicale by Klangforum Wien) and Rome where the festival Contratempo was in large part dedicated to my music. In October I am to receive the Golden Lion for Lifetime Achievement from the Venice Biennale - I admit that I have been truly touched by this prize. Machinations will be performed twice at the festival to mark the occasion. Otherwise, between various concerts, 2015 promises plenty of composing work. 
Q. Is the future bright for contemporary music?

A. As long as one is alive, one is contemporary with one's times. The music that one produces during one's life is therefore also contemporary. For as long as one lives, one can't do other than produce contemporary music. 